\title{
Mitral Valve Obstruction Caused by Heart-shaped Large Left Atrial Myxoma
}

\section{Mitral Kapak Obstrüksiyonuna Neden Olan Kalp Şekilli Dev Sol Atrial Miksoma}

\section{(D) Oktay ŞENÖZ1, (1) Ferhat YURDAM', (1) Fatma Nur TOMAKIN³, (D) Zeynep YAPAN EMREN1, (D) Volkan EMREN²}

'Bakırçay University, Çiğli Training and Research Hospital, Clinic of Cardiology, İzmir, Turkey 2izmir Kâtip Çelebi University, Atatürk Training and Research Hospital, Clinic of Cardiology, İzmir, Turkey

${ }^{3}$ Bakırçay University, Çiğli Training and Research Hospital, Department of Cardiovascular Surgery, İzmir, Turkey

Cite as: Şenöz O, Yurdam F, Tomakin FN, Yapan Emren Z, Emren V. Mitral Valve Obstruction Caused by Heart-shaped Large Left Atrial Myxoma. Forbes J Med. 2021;2(3):182-184.

\begin{abstract}
Myxoma is one of the most common benign primary cardiac tumors, usually detected at ages between 30 and 60 years. It accounts for $50 \%$ of the primary cardiac tumors. The most common location of a myxoma is the left atrium. Myxomas are more prevalent in females. The clinical outcomes can differ depending on the tumor's size, location, and architecture. The clinical picture can mimic mitral stenosis, which causes mitral valve obstruction. Syncope is a rare but life-threatening symptom and requires early surgical treatment. This paper describes a patient with a large left atrial myxoma, causing mitral valve obstruction.
\end{abstract}

Keywords: Myxoma, mitral valve obstruction, syncope, intracardiac mass

öz

Miksoma, çoğunlukla 30 ile 60 yaşlar arasında saptanan ve en sık görülen benign primer kardiyak tümördür. Primer kardiyak tümörlerin yaklaşık \%50'sini oluşturur. En sık sol atriyum yerleşimlidirler ve kadınlarda daha sık görülür. Miksomalar; büyüklüğüne, yüzey yapısına ve bulundukları kalp boşluklarına göre farklı klinik tabloya neden olabilirler. Mitral kapak obstrüksiyonuna neden olarak mitral darlığı semptomlarını ortaya çıarabilirler. Senkop nadir görülen ancak hayatı tehdit edebilen bir semptom olup erken cerrahi tedavi gerektirir. Bu yazıda mitral kapak obstrüksiyonuna neden olan dev sol atrial miksomalı nadir bir olgu sunulmuş̧ur.

Anahtar Kelimeler: Miksoma, mitral kapak obstrüksiyonu, senkop, intrakardiyak kitle
Received/Geliş: 22.03 .2021

Accepted/Kabul: 22.06 .2021

Corresponding Author/ Sorumlu Yazar:

Oktay ŞENÖZ MD

Bakırçay University, Çiğli Training and Research Hospital, Clinic of

Cardiology, İzmir, Turkey

Phone: +90 5068828129

oktayssss@hotmail.com ORCID: 0000-0002-3847-7598

${ }^{\circ}$ Copyright 2021 by the İzmir Buca Seyfi Demirsoy Training and Research Hospital / Forbes Journal of Medicine published by Galenos Publishing House. Licensed by Creative Commons Attribution 4.0 International (CC BY)

${ }^{\bullet}$ Telif Hakkı 2021 İzmir Buca Seyfi Demirsoy Eğitim ve Araştırma Hastanesi / Forbes Tıp Dergisi, Galenos Yayınevi tarafından yayınlanmıştır. Bu dergide yayınlanan bütün makaleler Creative Commons 4.0 Uluslararası Lisansı (CC-BY) ile lisanslanmıştır. 


\section{INTRODUCTION}

The incidence of rare primary cardiac tumors ranges from $0.0017 \%$ to $0.19 \%$. $^{.}$Myxoma is the most common benign cardiac primary tumor and accounts for $50 \%$ of the cardiac tumors. It is more prevalent in females., ${ }^{2,3}$ Although this tumor can be detected at any age, it is usually seen in the third and sixth decades of life. ${ }^{4}$ The clinical presentation has been linked to the tumor's size, location, and architecture. Myxoma has a wide clinical spectrum ranging from being asymptomatic to causing heart failure and pulmonary hypertension due to mitral valve obstruction. In some patients with huge myxomas, syncope can be an alarming symptom, requiring emergency surgery. ${ }^{1,5}$

\section{CASE REPORT}

A 77-year-old female patient presented to the emergency department with multiple syncopal episodes and new episodes of shortness of breath. She had a history of hypertension and chronic obstructive pulmonary disease. On physical examination, her blood pressure was 100/55 $\mathrm{mmHg}$, pulse rate was $98 / \mathrm{min}$, and arterial oxygen saturation $\left(\mathrm{SaO}_{2}\right)$ (using pulse oximetry) was $86 \%$. On auscultation, heart sounds were arrhythmic and 3/6 diastolic murmur was observed at the apex. Severe bilateral wheezing and fine crackles were observed at the lung bases. Chest X-ray showed highly increased cardiothoracic ratio, blunted right costophrenic sinus, and bilateral ground-glass appearance at the lung bases. A 12-lead electrocardiogram detected atrial fibrillation with nonspecific minor ST-T abnormalities. Echocardiography revealed a huge heterogeneous, irregular, and elliptical mass in a dilated atrium attached to the interatrial septum and compromised mitral valve functions (Figure 1). The mass caused a pseudomitral stenosis, with a maximal peak gradient of $15 \mathrm{mmHg}$ (Figure 2).

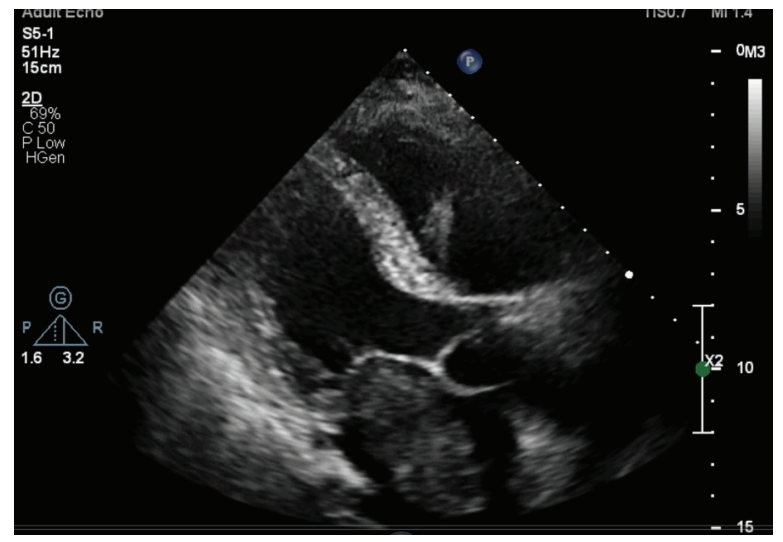

Figure 1. Long parasternal axis view of transthoracic echocardiography, showing a left atrial myxoma reaching the atrial surface of the mitral valve
The patient underwent emergency surgery. The patient first underwent median sternotomy and then right atriotomy for easily accessing the septal peduncle. An enormous mass was found inside the left atrium and was resected. No complications occurred. The septal defect was then closed with a pericardial patch. Macroscopically, the mass was heart-shaped. It consisted of three parts (atrial, ventricular, and neck formed by the mitral valve) (Figure 3). Histopathological examination demonstrated the characteristic acid mucopolysaccharide matrix-embedded polygonal cells, which confirmed the diagnosis of cardiac myxoma. The patient was taken to the cardiology ward after three days of intensive care monitoring. Subsequently, the patient was mobilized and uneventfully discharged.

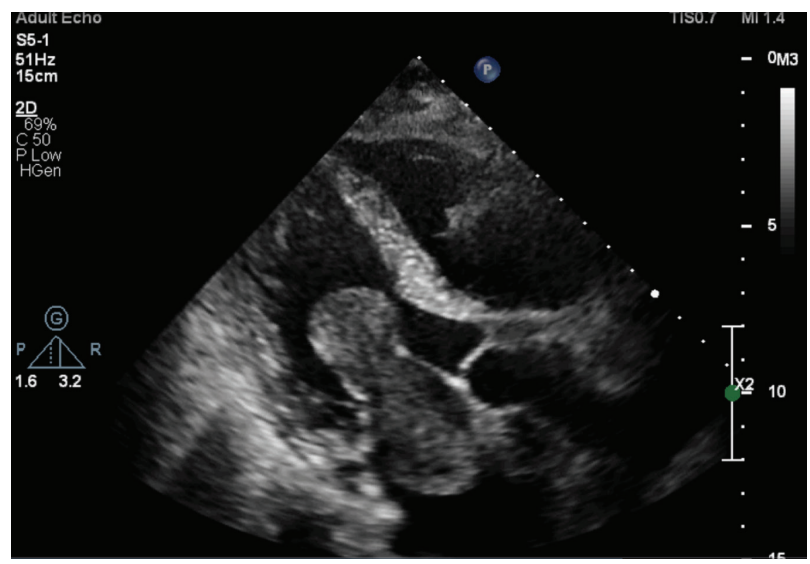

Figure 2. Long parasternal axis view of transthoracic echocardiography, demonstrating a large mobile left atrial myxoma prolapsing through the mitral valve

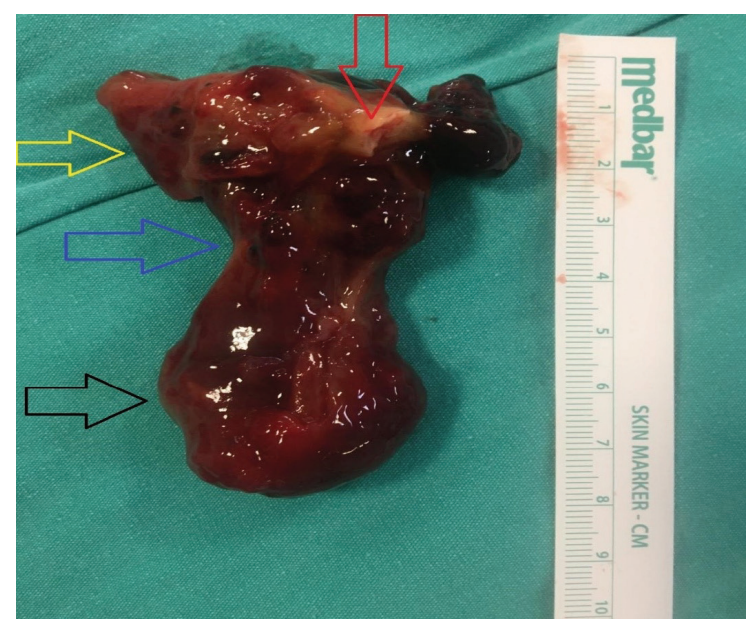

Figure 3. Macroscopic view of the postoperative heartshaped mass. Atrium-shaped (yellow arrow), ventricleshaped (black arrow), and neck-shaped, formed by the mitral valve (blue arrow) and area of attachment to the interatrial septum (red arrow) 


\section{DISCUSSION}

Myxoma is the most common benign primary cardiac tumor, accounting for $50 \%$ of the cardiac tumors. It is more prevalent in females. ${ }^{2}$ In $75 \%$ of the patients, the tumor is located in the left atrium, followed by the right atrium in 23\% of the patients and ventricles in $2 \%$ of the patients. Myxoma is rarely found in more than one cavity. ${ }^{6}$ Myxomas usually present with nonspecific signs and symptoms. However, they can be incidentally detected in asymptomatic patients. The clinical outcomes of myxomas can differ depending on their size, location, and architecture. The clinical presentation of myxoma includes cardiac (67\%), embolic (29\%), and systemic (34\%) symptoms and even sudden cardiac death in rare occasions. ${ }^{7}$ Tumors originating from the left atrium, especially if mobile and large, may mimic the symptoms of a mitral stenosis because they obstruct the atrioventricular blood flow. ${ }^{3}$ The symptoms include exertional dyspnea, paroxysmal nocturnal dyspnea, orthopnea, fatigue, and syncope. Our patient experienced symptoms of mitral valve obstruction, including dyspnea, syncope, and pulmonary edema. Diastolic murmur due to valve obstruction can be seen in myxoma. Although rare, the "tumor plop" sound is one of the classic and characteristic auscultatory findings of cardiac myxomas and helps diagnose cardiac tumors. ${ }^{8}$ The "tumor plop" of myxoma is a protodiastolic murmur heard 80-150 ms after S2, which may be mistaken for an opening snap. ${ }^{7}$

Echocardiography is the most important imaging method for diagnosing cardiac tumors. Myxoma often has heterogeneous echogenicity with occasional calcifications. The myxoma's location in the left atrium and origin from the atrial septum are hallmark findings for diagnosis. These clues help differentiate myxoma from other cardiac masses. Transthoracic echocardiogram is usually sufficient to diagnose myxomas, but if the results were suboptimal, transesophageal echocardiogram should be performed. ${ }^{5}$

Embolization of an aneurysm in the central nervous system (CNS) could be associated with myxomas. Performing a brain magnetic resonance imaging scan is recommended in all patients with cardiac myxomas to exclude manifestations of the CNS. ${ }^{9}$

Sudden death in patients with cardiac myxomas is attributed to severe acute disturbance of the cardiac hemodynamics caused by cardiac mass obstruction or coronary embolization of the tumor. ${ }^{7}$ Therefore, early surgery is essential in patients with cardiac myxomas. Cardiac myxomas can cause complete intracardiac obstruction. ${ }^{10}$ Macroscopic and microscopic pathological examination of intracardiac masses must be performed after surgical excision, and the invasive potential of the mass must be examined to exclude malignancy.

\section{CONCLUSION}

Patients with myxoma may present with syncope or symptoms of heart failure, such as dyspnea. Echocardiography is a valuable diagnostic tool in patients with cardiac masses. Surgical removal is the first choice of treatment in myxomas. Surgical excision of the mass helps reduce complications as myxomas can grow rapidly in size, which can cause obstructive and embolic phenomena.

\section{Ethics}

Informed Consent: Consent form was filled out by all participants.

Peer-review: Externally peer-reviewed.

\section{Authorship Contributions}

Surgical and Medical Practices: F.N.T., Z.Y.E., Concept: O.Ş., Design: O.Ş., Data Collection or Processing: F.Y., Analysis or Interpretation: V.E., Literature Search: V.E., F.Y., Writing: O.Ş.

Conflict of Interest: No conflict of interest was declared by the authors.

Financial Disclosure: The authors declared that this study received no financial support.

\section{REFERENCES}

1. Butany J, Nair V, Naseemuddin A, Nair GM, Catton C, Yau T. Cardiac tumours: diagnosis and management. Lancet Oncol. 2005;6:219-28.

2. Tasoglu I, Tutun U, Lafci G, et al. Primary cardiac myxomas: clinical experience and surgical results in 67 patients. J Card Surg. 2009;24:256-9.

3. Pinede L, Duhaut P, Loire R. Clinical presentation of left atrial cardiac myxoma. A series of 112 consecutive cases. Medicine (Baltimore). 2001;80:159-72.

4. Parry AJ, Pillaj R. Miscellaneous cardiac disease. In: Morris PJ, Malt RA (ed). Oxford Textbook of Surgery, Vol 2, 1994, Oxford: Oxford University Press:1848-54.

5. Rashidi N, Montazeri M, Montazeri M. Large Left Atrial Myxoma Causing Mitral Valve Obstruction: A Rare Cause of Syncope. J Cardiovasc Echogr. 2014;24:125-7.

6. El Sabbagh A, Al-Hijji MA, Thaden JJ, et al. Cardiac Myxoma: The Great Mimicker. JACC Cardiovasc Imaging. 2017;10:203-6.

7. Spartalis M, Tzatzaki E, Spartalis E, et al. Atrial Myxoma Mimicking Mitral Stenosis. Cardiol Res. 2017;8:128-30.

8. Pitt A, Pitt B, Schaefer J, Criley JM. Myxoma of the left atrium. Hemodynamic and phonocardiographic consequences of sudden tumor movement. Circulation. 1967;36:408-16.

9. Baikoussis NG, Siminelakis SN, Kotsanti A, Achenbach K, Argyropoulou M, Goudevenos J. Multiple cerebral mycotic aneurysms due to left atrial myxoma: are there any pitfalls for the cardiac surgeon? Hellenic J Cardiol. 2011;52:466-8.

10. Ren DY, Fuller ND, Gilbert SAB, Zhang Y. Cardiac Tumors: Clinical Perspective and Therapeutic Considerations. Curr Drug Targets. 2017;18:1805-9. 